\title{
EFFECT OF HIGH PRESSURE PROCESSING ON MILK COAGULATION PROPERTIES
}

\author{
Marika Liepa, Jelena Zagorska, Ruta Galoburda \\ Latvia University of Agriculture \\ marikaliepa@gmail.com
}

\begin{abstract}
Raw milk cheeses are known to have more intense and strong flavour and different texture due to natural microbiota and enzymes. Nevertheless, there are concerns about safety of these products. For microbial inactivation heat treatment of milk is used, but it can adversely affect the flavour, taste and texture of the product. Therefore, applying non-thermal technology such as high pressure processing is attracting alternative. The aim of this study was to examine the effects of high pressure treatment of cow`s milk at a wide range of pressures (400 - $600 \mathrm{MPa})$ on milk rennet coagulation time, curd firmness and curd yield. Processed milk samples were subjected to enzymatic coagulation using commercial rennet to determine rennet coagulation time, yield of coagulum and curd firmness. High pressure processing insignificantly influences coagulation properties of whole milk. However, the magnitude of changes depended on applied pressure. Rennet coagulation time and curd yield were significantly different ( $p$ $<0.05$ ) among the pressure treated milk samples. The higher firmness of the curd form pressurized milk than that of raw or pasteurized milk, evaluated positively. The main effects of high pressure treatment in milk appeared to involve dissociation of casein micelles from the colloidal to the soluble phase. This study suggests that high pressure treatments of milk at $500 \mathrm{MPa}$ or $550 \mathrm{MPa}$ for 15 min may be beneficial for improving the coagulation properties of milk. These positive effects indicated that high pressure processing may have potential for new cheese varieties development.
\end{abstract}

Key words: high pressure, enzymatic coagulation, compression method.

\section{Introduction}

Cheese manufacture is one of the classical examples of food preservation, dating from 6000 7000 BC. There are more than 1000 varieties of cheese produced throughout the world, created by differences in milk source, fermentation and ripening conditions as well as pressing, size and shape (Young \& George, 2013). Cheese processing is a complex process involving many steps. The rennet coagulation of milk is one of the first and most important steps in a cheese making process.

The milk coagulation properties are of a great importance as they influence cheese yield and quality. The suitability of milk for cheese making is evaluated by measuring the time required for curdfirming, rennet coagulation time (RCT), the firmness, permeability, contractility, and syneresis of curd. In addition, it is very essential to obtain the maximum achievable recovery of substance from milk because the higher the recovered percentage of solids, the greater the amount of cheese obtained and therefore gain in economic terms (Chopde, Deshmukh, \& Kalyankar, 2014). The yield of cheese is influenced by different factors: the composition of the milk, the species and breed of animal, milk quality and the stage of lactation. Furthermore, pre-treatment (microfiltration, homogenisation, milk maturation et al.) of milk can also increase the outcome of cheese (Huppertz et al., 2005).

The majority of cheeses are made from heattreated or pasteurised milk (either whole, low-fat or non-fat). Thermal processing is often used to insure safety and quality of cheese milk. However, heat treatment induces many unfavourable changes in sensory properties of cheese, including modifications in texture (Grappin \& Beuvier, 1997; Chawla, Patil, \& Singh, 2011). High pasteurization temperature (78 - $95{ }^{\circ} \mathrm{C}$ ) causes impaired clotting properties and a weaker curd; it appreciably reduces the curd firmness and increases RCT of milk (Huppertz et al., 2005). For this reason heat-treated milk is less suitable for cheese manufacturing. That is why during the last decades, food research has focused on the development of non-thermal technologies including high pressure processing.

The high pressure technology has emerged as an alternative to traditional thermal processing methods for foods including milk and dairy products (MuñozCuevas et al., 2013). High hydrostatic pressure processing of milk at room temperature causes several protein (whey proteins and caseins) modifications, such as reduction in the size of casein micelles and denaturation of $\beta$-lactoglobulin and $\alpha$-lactalbumin (O'Reilly et al., 2001). In a model of the casein micelle, colloidal calcium phosphate crosslinks the sub-micelles caseins and neutralises negatively charged phosphoserine groups, allowing the formation of hydrophobic interactions between caseins (Horne, 1998). Under pressure, hydrophobic and electrostatic interactions between proteins are disrupted and colloidal calcium phosphate is solubilised (LopezFandiño \& Olano, 1998). As a result, considerable changes in the size, structure and composition of the casein micelles occur (Huppertz, Fox, \& Kelly, 2004a). These changes are leading to modification in the technological parameters of cheese milk (rennet 
coagulation time, curd firmness) and improving milk coagulation properties and cheese yield (Huppertz et al., 2005; Pandey, Ramaswamy, \& St-Gelais, 2003; Trujillo et al., 2002).

Whole milk is commonly used for cheese making and microbiological quality of raw material is a significant factor affecting cheese quality. Our previous studies about milk microbiological quality conducted that optimal regime for milk processing is at least $400 \mathrm{MPa}$ for $15 \mathrm{~min}$ (Liepa et al., (2016) in press). Data about whole milk structural changes and coagulation properties in scientific literature is limited and poor. Therefore, the study of changes in coagulation properties induced by high pressure processing in whole milk is important. However, most research works in this area are focused on skim milk or heated milk. So the evaluation of influence of high pressure processing on coagulation ability of whole raw milk is necessary. The primary objective of the present study was to examine the effects of high pressure treatment of cow`s milk at a wide range of pressures $(400-600 \mathrm{MPa})$ on milk rennet coagulation time, curd firmness and curd yield.

\section{Materials and Methods}

The study object

Bulk milk samples were collected from the morning milking according to the standard LVS 175:1999 'Sampling of raw milk procedure'. After collection, milk samples were transported to the laboratory of the Faculty of Food Technology, Latvia University of Agriculture (Liepa et al., (2017) in press).

\section{High pressure and heat treatment of milk}

Milk was filled in polyethylene terephthalate (PET) plastic bottles (NF2 - $\varnothing 28 \mathrm{~mm}, 120 \pm 10 \mathrm{~mL}$ ), avoiding any head space, and vacuum sealed in polyethylene pouches $(70 \times 200 \mathrm{~mm}$ sized, with $65 \mu \mathrm{m}$ thickness $)$ using a chamber type vacuum packaging machine Multivac C350 (MULTIVAC Sepp Haggenmüller SE \& Co. KG, Germany) before being pressurized. Milk samples were pressure treated in a pressure chamber of $10 \mathrm{~cm}$ diameter and $23 \mathrm{~cm}$ length of the Iso-Lab High
Pressure Pilot Food Processor S-FL-100-250-09-W (Stansted fluid power LTD, UK). Milk underwent high pressure treatment, regimes indicated in Table 1. The pressurization was completed at room temperature. Product temperature increased during pressurization up to $30{ }^{\circ} \mathrm{C}$ and dropped during pressure release to about $17^{\circ} \mathrm{C}$ (Liepa et al., (2017) in press).

High pressure processing was compared to the high-temperature short-time (HTST) pasteurization at $78{ }^{\circ} \mathrm{C}$ for $15-20 \mathrm{~s}$.

Totally, 18 milk samples (6 samples in triplicate) were analyzed (Table 1).

\section{Analysis of milk coagulation parameters}

The $\mathrm{pH}$ of milk was determined using $\mathrm{pH}$ meter ino-LAB pH 720 (Germany) at the temperature $20{ }^{\circ} \mathrm{C}$ before the rennet coagulation analysis in raw, pasteurized and HP treated milk samples.

Prior the assessment of milk coagulation properties, milk samples were heated to the renneting temperature $35^{\circ} \mathrm{C}$. Rennet coagulation time (RCT) is a measurement of the time elapsed between the addition of a known amount of rennet to a known volume of milk at a given temperature and the onset of clotting, assessed visually (Ciprovica, Zagorska, \& Petrovska, 2016). RCT in minutes was analysed using $2: 10000$ (v/v) of rennet (CHY-MAX $1000 \mathrm{IMCU} \mathrm{mL}^{-1}$, Chr. Hansen, Denmark) solution into water and measuring the time until flocculation of milk was started at $35{ }^{\circ} \mathrm{C}$. For interpretation of results, all samples were divided into four groups (fast, average, slow and noncoagulating milks) based on the time devoted for the clotting of samples. The assessment of clotting was following: fast means flocculation formation less than $10 \mathrm{~min}$, average - during 10 - $15 \mathrm{~min}$, slow -more than 15 min (Ciprovica, Zagorska, \& Petrovska, 2016).

The same enzyme used in the analyses of curd firmness was diluted in to water 2: $100(\mathrm{v} / \mathrm{v})$. The added amount of rennet, process temperature and time for curd firmness measurement were adapted from methodology using Formagraph (Foss, Denmark) unit. The curd firmness was determined after $30 \mathrm{~min}$ of milk renneting using Texture Analyser TA.HD

Table 1

Milk samples description

\begin{tabular}{|l|l|}
\hline \multicolumn{1}{|c|}{ Sample abbreviation } & \multicolumn{1}{c|}{ Treatment applied to milk } \\
\hline Control & raw milk \\
\hline PM & heat-treated at $78^{\circ} \mathrm{C}$ for $15-20 \mathrm{~s}$ \\
\hline HPM 400 & high pressure treated at $400 \mathrm{MPa}$ for $15 \mathrm{~min}$ \\
\hline HPM 500 & high pressure treated to $500 \mathrm{MPa}$ for $15 \mathrm{~min}$ \\
\hline HPM 550 & high pressure treated to $550 \mathrm{MPa}$ for $15 \mathrm{~min}$ \\
\hline HPM 600 & high pressure treated to $600 \mathrm{MPa}$ for $15 \mathrm{~min}$ \\
\hline
\end{tabular}


Effect of treatment on whole milk pH and coagulation properties

\begin{tabular}{|l|c|c|c|c|}
\hline \multicolumn{1}{|c|}{ Sample } & $\mathrm{pH}$ & Rennet coagulation time, min & $\begin{array}{c}\text { Curd yield, } \\
\text { g 100g-1 }\end{array}$ & Curd firmness, N \\
\hline Control & $6.78 \pm 0.02^{\mathrm{b}}$ & $9.21 \pm 0.05^{\mathrm{e}}$ & $22.40 \pm 0.78^{\mathrm{c}}$ & $1.72 \pm 0.42^{\mathrm{b}}$ \\
\hline PM & $6.80 \pm 0.01^{\mathrm{ab}}$ & $15.21 \pm 0.11^{\mathrm{a}}$ & $23.57 \pm 0.47^{\mathrm{bc}}$ & $0.85 \pm 0.08^{\mathrm{c}}$ \\
\hline HPM 400 & $6.80 \pm 0.02^{\mathrm{ab}}$ & $9.27 \pm 0.04^{\mathrm{e}}$ & $24.17 \pm 0.35^{\mathrm{bc}}$ & $2.79 \pm 0.32^{\mathrm{a}}$ \\
\hline HPM 500 & $6.81 \pm 0.02^{\mathrm{a}}$ & $10.01 \pm 0.37^{\mathrm{d}}$ & $24.73 \pm 0.32^{\mathrm{b}}$ & $2.82 \pm 0.18^{\mathrm{a}}$ \\
\hline HPM 550 & $6.81 \pm 0.01^{\mathrm{a}}$ & $10.46 \pm 0.10^{\mathrm{c}}$ & $25.60 \pm 0.50^{\mathrm{b}}$ & $2.86 \pm 0.42^{\mathrm{a}}$ \\
\hline HPM 600 & $6.82 \pm 0.01^{\mathrm{a}}$ & $11.15 \pm 0.04^{\mathrm{b}}$ & $33.07 \pm 2.48^{\mathrm{a}}$ & $2.40 \pm 0.03^{\mathrm{a}}$ \\
\hline
\end{tabular}

Duncan's test: different letters (a-e) in the same row indicate significant differences among treatments $(\mathrm{p}<0.05)$

plus (Stable Micro Systems LTD, UK). Compression method for determination of curd firmness (disc $\mathrm{A} / \mathrm{BE}-\mathrm{d} 45$, test speed $1.0 \mathrm{~mm} \mathrm{~s}^{-1}$, distance in the depth of curd sample $8 \mathrm{~mm}$ ) was used (Ciprovica, Zagorska, \& Petrovska, 2016).

\section{Statistical analysis}

Experiments were conducted triplicate and the means of the three data are presented. Duncan's multiple range test was used to determine the significance among mean values of untreated and treated samples. The obtained data were processed using Microsoft Excel (Microsoft Office Enterprise 2007, License: Shareware $\boldsymbol{N} / \boldsymbol{A}$ ); differences among results were considered significant if p-value $<0.05$. For the interpretation of the results, it was assumed that $\alpha=0.05$ with $95 \%$ confidence.

\section{Results and Discussion}

Our previous studies showed the high pressure effect on milk microbiological quality (decrease of colony forming units) (Liepa et al., (2016) in press) and sensory properties (Liepa et al., (2017) in press), but for better understanding how pressure can influence milk properties and for which cheese variety this method of treatment would be the most appropriate, the milk coagulation properties of whole milk were evaluated during this step of research.

\section{Effect of HP treatment on $\mathrm{pH}$}

$\mathrm{pH}$ values of analysed milk samples are shown in Table 2. This parameter ranged between $6.78 \pm$ 0.02 and $6.82 \pm 0.01$. High pressure treatment due to casein micelle disaggregation alters the distribution of minerals and raises the concentration of ionic calcium in milk. As a result of an increase in the concentration of phosphate in the milk serum, an increase in milk pH occurs (Chopde et al., 2014; Zobrist et al., 2005). In the present study, high pressure increased the $\mathrm{pH}$ value, which was lower in raw milk. $\mathrm{pH}$ of pasteurized milk was similar to that of HPM 400 sample - 6.80 . Heat treatment and pressurization at $400 \mathrm{MPa}$ had little influence on $\mathrm{pH}$ of whole milk; analysed parameter values of control sample, PM and HPM 400 samples were not significantly different $(\mathrm{p}>0.05)$. The differences in the $\mathrm{pH}$ also were not significant $(\mathrm{p}>0.05)$ among all high pressure treated milk samples; however, high pressure treatment at pressure $500 \mathrm{MPa}$ affected $\mathrm{pH}$ of milk considerably $(\mathrm{p}<0.05)$, compared with a control sample. Other authors (Huppertz et al., 2005; Zobrist et al., 2005) also found an increase in $\mathrm{pH}$ that depended on treatment pressure and time.

\section{Effect of HP treatment on rennet coagulation time of milk}

Rennet coagulation time (RCT) is an index of the gelation potential of milk. In the present study, a control sample had the lowest RCT $-9.21 \pm 0.05 \mathrm{~min}$, whereas pasteurized milk had the highest RCT (15.21 $\pm 0.11 \mathrm{~min}$ ) (Table 2). Thus, heat treatment of milk increased the RCT by $65 \%$ (Figure 1). Pasteurization induces the association of denatured whey proteins with the casein micelles, what result in deterioration of milk coagulation properties (Anema, 2008; Haq et al., 2014; Huppertz et al., 2005).

According to the recommendations for cheese processors, the best rennet coagulation time is from 10 to $15 \mathrm{~min}$ (Горбатова \& Гунькова, 2010); НРМ 500,550 , and 600 samples belong to this group. At the same time raw and pasteurized milk belongs to the groups, which are not so suitable for cheese processing - too fast or too slow, respectively.

A number of studies (Huppertz et al., 2005; LópezFandiño, 2006; Trujillo et al., 2002; Zobrist et al., 2005) have indicated that the magnitude and nature of the effect of high pressure treatment on RCT of milk depends on the applied pressure. In the present study, pressure treated whole milk samples obtained intermediate RCT values. As shown in Figure 1, the RCT of milk after treatment at/or above $400 \mathrm{MPa}$, is equal to/or longer than that of raw milk. Compared to the control sample, treatment at 400, 500, and 550 $\mathrm{MPa}$ had a little effect on RCT (increase by $0.6 \%$, 


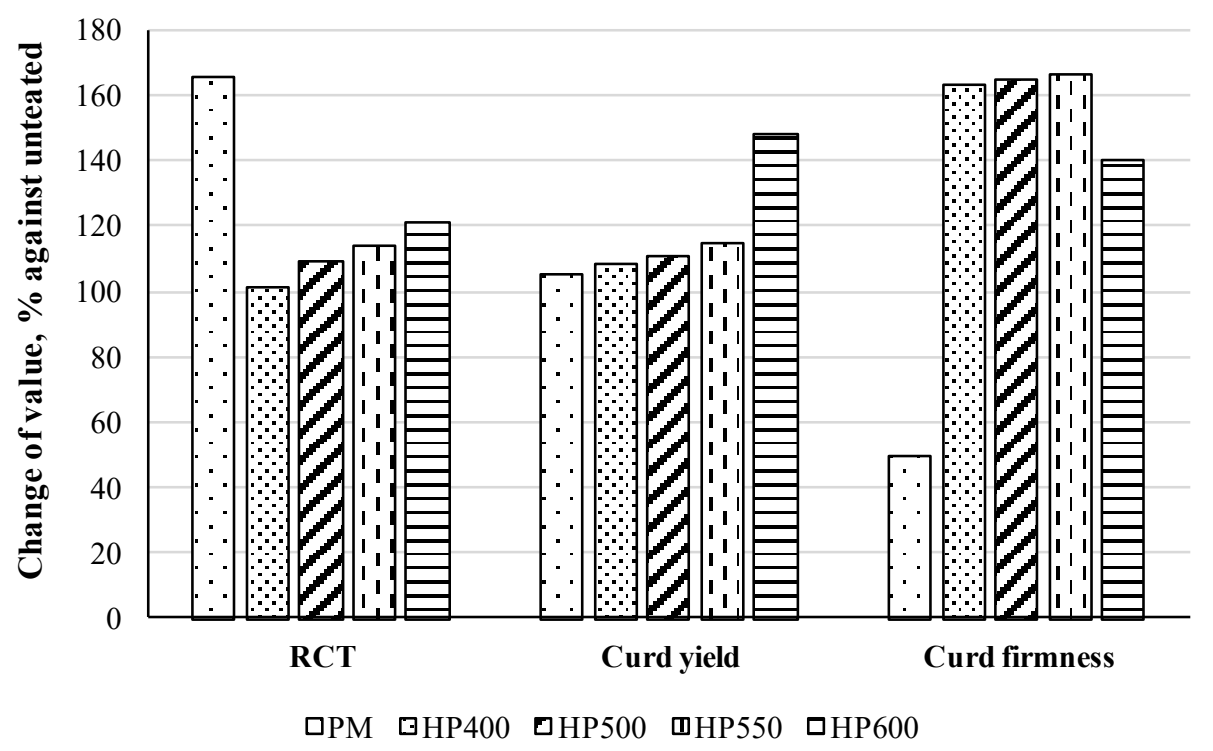

Figure 1. Effect of heat and high pressure treatments on the rennet coagulation time, curd yield and curd firmness of milk samples.

$8.7 \%$ and $13.5 \%$ respectively), but treatment at 600 $\mathrm{MPa}$ increased this parameter significantly $(\mathrm{p}<0.05)$ by $21.1 \%$. An increase in the rennet coagulation time at higher pressure results from association of denatured whey proteins with the casein micelles (Huppertz \& Kelly, 2005). The RCT increase after high pressure treatment was consistent with the previous reports (López-Fandiño, 2006; Lopez-Fandiño \& Olano, 1998; Needs et al., 2000; Zobrist et al., 2005).

Voigt et al. (2010) observed reduction by $11.1 \%$ and $37.4 \%$ of RCT of at first pasteurised $\left(63{ }^{\circ} \mathrm{C} / 30 \mathrm{~min}\right)$ and then pressurised at 400 and 600 $\mathrm{MPa}\left(20^{\circ} \mathrm{C} / 10 \mathrm{~min}\right)$ whole milk, respectively. High pressure treatment at $400-600 \mathrm{MPa}$ induced increase of RCT of unheated milk is due to the association of whey proteins with the casein micelles (Needs et al., 2000; Zobrist et al., 2005), while similar pressurization of heated milk reduces RCT greatly. This demonstrates structural differences between casein micelles of unheated, pasteurized and pressurised milk although the level of denaturation is comparable (Huppertz, Fox, \& Kelly, 2004a).

\section{Effect of HP treatment on curd firmness}

One of the most important factors in manufacturing of cheese is the production of a satisfactory curd. It is required to have a sufficiently firm curd for production of good quality cheese. A heat treatment induced significant decrease $(p<0.05)$ in the firmness of the curd made from raw milk (if pasteurization temperature $78{ }^{\circ} \mathrm{C}$ was applied). In the present study, pasteurized milk had the lowest curd firmness - 0.85 $\pm 0.08 \mathrm{~N}$ (Table 2). The effect of heat treatment on the rheological parameters of milk could be attributed mainly to the denaturation of proteins and colloidal salt formation. The interactions of whey protein with casein micelles interfere with the rennet coagulation process, resulting in weak curd structures of heat treated milk (Ustunol, 1983).

Compared to pasteurized milk and control sample, high pressure treatment increased curd firmness significantly $(p<0.05)$. The rennet-induced curd formed from pressurized milk increases with pressure $400-550 \mathrm{MPa}$, followed by a decrease at $600 \mathrm{MPa}$ (Figure 1). Notwithstanding that curd yield of HPM 600 sample was the highest, the curd firmness of this sample was the lowest $(2.40 \pm 0.03 \mathrm{~N})$ among the high pressure treated milk samples; meanwhile HP $550 \mathrm{MPa}$ sample had the highest curd firmness - 2.86 \pm 0.42 N. Also, Needs et al. (2000) reported curd firmness values of pressure treated milk (at 200 - 600 $\mathrm{MPa})$ was higher than values of untreated milk. The curd firmness of unheated pressurized at $600 \mathrm{MPa}$ milk was lower, compared to at $400 \mathrm{MPa}$ treated milk. Zobrist et al. (2005) suggested that this may be due to the association of denatured $\alpha$-lactalbumin with casein micelles that result in obstructing of gelation process.

\section{Effect of HP treatment on curd yield}

The effect of treatment on curd yield of whole cow`s milk is shown in Table 1 . The yield of curd from heat treated milk and milk treated at 400 MPa differed only slightly from that of untreated milk; however, treatment at 500,550 or $600 \mathrm{MPa}$ significantly $(\mathrm{p}<0.05)$ increased curd yield by 10 , 14 or $47 \%$, respectively (Figure 1). High pressure induced increase of curd yield is probably due to the denaturation of whey proteins and increasing of 


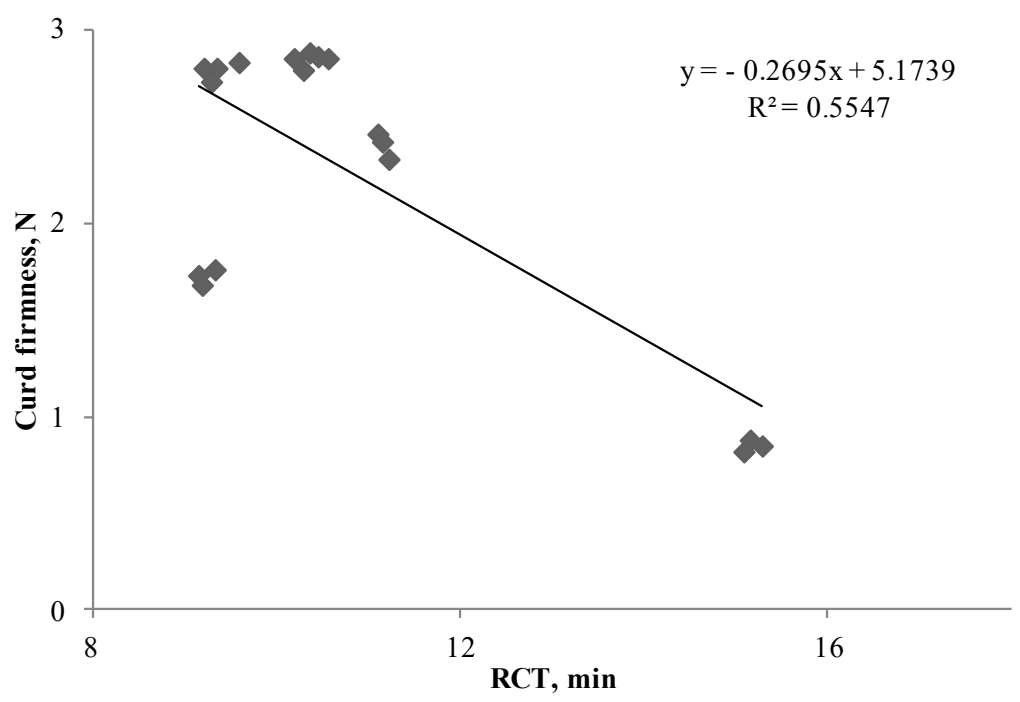

Figure 2. Correlation between RCT and curd firmness in analyzed milk samples.

moisture retention (Pandey et al., 2003) that can be more suitable for soft and fresh cheese production. Our previous study (Liepa et al., (2017) in press) found significant difference $(\mathrm{p}<0.05)$ between milk colour before and after high pressure processing. After high pressure treatment product became more yellowish, this fact can partly prove disintegration of casein micelles during pressurizing. More detailed explanation can be given by assessing structure of milk protein after high pressure treatment, its content in whey and water content in curd; therefore, further research should be done. An increase in curd yield after treatment at a pressure $\geq 400 \mathrm{MPa}$ was in agreement with previous reports (Huppertz, Fox, \& Kelly, 2004b; Lopez-Fandiño \& Olano, 1998).

The differences in curd firmness could be related to rennet coagulation time of milk samples. The correlation between RCT and firmness values is presented in Figure 2. In the present study, strong negative correlation $(r=0.75)$ between RCT and curd firmness was determined.

HPM 500 and HPM 550 samples belong to group, which is suitable for cheese processing (through its RCT values), and simultaneously having the highest curd firmness among all milk samples. At the same time, control sample and heat treated milk have lower suitability for cheese processing due to its undesirable RCT values and the lowest curd firmness.

Comparing coagulation properties (rennet coagulation time, curd yield, and firmness) of milk during research best results among all analysed samples were obtained from milk samples treated at
500 and $550 \mathrm{MPa}$ during $15 \mathrm{~min}$. Further research (cheese making process, cheese quality, maturation, economical aspects) should be done to make significant conclusions about high pressure suitability for cheese production.

\section{Conclusions}

High pressure processing insignificantly influences coagulation properties of raw milk, however, the magnitude of changes depended on treatment pressure and time.

The higher firmness of the curd from pressurized milk than that of raw or pasteurized (at $78{ }^{\circ} \mathrm{C}$ for $15-20 \mathrm{~s}$ ) milk was evaluated positively. After high pressure processing the curd yield was increased by for 7 to $47 \%$ due to a combination of incorporation of denatured whey proteins in the curd.

Average RCT values were observed in all pressure treated raw milk samples.

Results from current study suggest that treatment of milk at $500 \mathrm{MPa}$ or $550 \mathrm{MPa}$ for $15 \mathrm{~min}$ could be optimal for new cheese varieties development.

\section{Acknowledgement}

Present theoretical research and practical investigations have been supported by the National research programme 'Agricultural Resources for Sustainable Production of Qualitative and Healthy Foods in Latvia' (AgroBioRes) (2014 - 2017), project No. 4 'Sustainable use of local agricultural resources for qualitative and healthy food product development' (FOOD)

\section{References}

1. Anema, S.G. (2008). Heat and/or high-pressure treatment of skim milk: Changes to the casein micelle size, whey proteins and the acid gelation properties of the milk. International Journal of Dairy Technology, 61(3), 245 - 252. DOI: 10.1111/j.1471-0307.2008.00418.x. 
2. Chawla, R., Patil, G., \& Singh, A. (2011). High hydrostatic pressure technology in dairy processing: A review. Journal of Food Science and Technology, 48(3), 260 - 268. DOI: 10.1007/s13197-010-0180-4.

3. Chopde, S.S., Deshmukh, M.A., \& Kalyankar, S.D. (2014). High pressure technology for cheese processing - a review. Asian J. Dairy \& Food Research, 33(4), 239 - 245. DOI: 10.5958/09760563.2014.00610.1.

4. Chopde, S.S., Deshmukh, M.A., Kalyankar, S.D., \& Changade, S.P. (2014). Applications of high pressure technology for milk processing. Research Journal of Animal Husbandry and Dairy Science, 5(2), 143 147. DOI: 10.15740/HAS/RJAHDS/5.2/143-147.

5. Ciprovica, I., Zagorska, J., \& Petrovska, S. (2016). The potencial of Latvian cows' breeds on cheesemaking. III International conference 'Industrial Technologies and Engineering' (ICITE - 2016): proceedings, Shymkent, Kazakhstan, October 28 - 29, 2016 / M. Auezov South Kazakhstan State University. - Shymkent, 2016. - Vol.2, p. $16-21$.

6. Grappin, R., \& Beuvier, E. (1997). Possible implications of milk pasteurization on the manufacture and sensory quality of ripened cheese. International Dairy Journal, 7(12), 751 - 761. DOI: 10.1016/S09586946(98)00006-5.

7. Haq, I., Khaskheli, M., Salman, M., Marri, M.Y., Ali, I., Marri, M.A., ... Kiani, F.A. (2014). Effect of heat treatments on sensory characteristics and shelf-life of skimmed milk. African Journal of Food Science, 8 (February), 75 - 79. DOI: 10.5897/AJFS2013.1099.

8. Horne, D.S. (1998). Casein interactions: Casting light on the black boxes, the structure of dairy products. International Dairy Journal, 8, 171 - 177. DOI: 10.1016/S0958-6946(98)00040-5.

9. Huppertz, T., Fox, P.F., \& Kelly, A.L. (2004a). Dissociation of caseins in high pressure-treated bovine milk. International Dairy Journal, 14(8), 675 - 680. DOI: 10.1016/j.idairyj.2003.11.009.

10. Huppertz, T., Fox, P.F., \& Kelly, A.L. (2004b). Effects of high pressure treatment on the yield of cheese curd from bovine milk. Innovative Food Science \& Emerging Technologies, 5(1), 1 - 8. DOI: 10.1016/j. ifset.2003.09.001.

11. Huppertz, T., Hinz, K., Zobrist, M. R., Uniacke, T., Kelly, A.L., \& Fox, P.F. (2005). Effects of high pressure treatment on the rennet coagulation and cheese-making properties of heated milk. Innovative Food Science \& Emerging Technologies, 6(3), 279 - 285. DOI: 10.1016/j.ifset.2005.03.005.

12. Huppertz, T., \& Kelly, A. (2005). Milk Treatment Under Pressure. Dairy Industries International, (May), $28-31$.

13. Liepa, M., Zagorska, J., Galoburda, R., \& Kostascuka, S. (2016). Effect of high-pressure processing on microbial quality of skimmed milk. $2^{\text {nd }}$ International Conference 'Nutrition and Health', 05. - 07.10.2016., Rīga (LU; RSU; LLU), Proceedings of the Latvian Academy of Sciences. Section B. Natural, Exact, and Applied Sciences/ The Journal of Latvian Academy of Sciences, In press.

14. Liepa, M., Zagorska, J., Galoburda, R., Straumite, E., Kruma, Z., \& Sabovics, M. (2017). Sensory properties of high-pressure treated milk. In press.

15. López-Fandiño, R. (2006). High pressure-induced changes in milk proteins and possible applications in dairy technology. International Dairy Journal, 16(10), 1119 - 1131. DOI: 10.1016/j.idairyj.2005.11.007.

16. Lopez-Fandiño, R., \& Olano, A. (1998). Cheese-making properties of ovine and caprine milks submitted to high pressures. International Dairy Journal, (78), 341 - 350. DOI: 10.1016/S09586946(98)00006-5.

17. Muñoz-Cuevas, M., Guevara, L., Aznar, A., Martínez, A., Periago, P.M., \& Fernández, P.S. (2013). Characterisation of the resistance and the growth variability of Listeria monocytogenes after high hydrostatic pressure treatments. Food Control, 29(2), 409 - 415. DOI: 10.1016/j.foodcont.2012.05.047.

18. Needs, E.C., Stenning, R., Gill, L., Ferragut, V., \& Rich, G.T. (2000). High-pressure treatment of milk: effects on casein micelle structure and on enzymic coagulation. The Journal of Dairy Research, 67(1), 31 - 42. DOI: 10.1017/S0022029999004021.

19. O’Reilly, C.E., Kelly, A.L., Murphy, P.M., \& Beresford, T.P. (2001). High pressure treatment: Applications in cheese manufacture and ripening. Trends in Food Science and Technology, 12(2), 51 - 59. DOI: 10.1016/ S0924-2244(01)00060-7.

20. Pandey, P.K., Ramaswamy, H.S., \& St-Gelais, D. (2003). Effect of high pressure processing on rennet coagulation properties of milk. Innovative Food Science \& Emerging Technologies, 4(3), 245 - 256. DOI: 10.1016/S1466-8564(03)00034-1.

21. Trujillo, A.J., Capellas, M., Saldo, J., Gervilla, R., \& Guamis, B. (2002). Applications of high-hydrostatic pressure on milk and dairy products: A review. Innovative Food Science and Emerging Technologies, 3(4), 295 - 307. DOI: 10.1016/S1466-8564(02)00049-8. 
22. Ustunol, Z. (1983). Effects of Heat Treatment and Posttreatment Holding Time on Rennet Clotting of Milk. All Graduate Theses and Dissertations, 77. DOI: 10.3168/jds.S0022-0302(85)80854-7.

23. Voigt, D.D., Donaghy, J.A., Patterson, M.F., Stephan, S., \& Kelly, A.L. (2010). Manufacture of Cheddar cheese from high-pressure-treated whole milk. Innovative Food Science and Emerging Technologies, 11(4), 574 - 579. DOI: 10.1016/j.ifset.2010.08.003.

24. Zobrist, M.R., Huppertz, T., Uniacke, T., Fox, P.F., \& Kelly, A.L. (2005). High-pressure-induced changes in the rennet coagulation properties of bovine milk. International Dairy Journal, 15(6-9), 655 - 662. DOI: 10.1016/j.idairyj.2004.07.025.

25. Young, W.P., \& George, F.W. (2013). Milk and Dairy Products in Human nutrition. West Sussex: John Wiley \& Sons Ltd. Retrieved January 15, 2017, from: http://www.fao.org/docrep/018/i3396e/i3396e.pdf.

26. Горбатова, К.К., Гунькова, П.И. (2010). Биохимия молока и молочных продуктов. (Вiochemistry of milk and dairy products). СПб.: ГИОРД, - 330 c. ISBN: 976-5-98879-112-6. (in Russian). 